\title{
Use of Water by Eastern Hemlock: Implications for Systemic Insecticide Application
}

\author{
Chelcy R. Ford, James M. Vose, Michael Daley, and Nathan Phillips
}

\begin{abstract}
The hemlock woolly adelgid (HWA; Adelges tsugae Annand) is causing widespread decline and mortality of eastern hemlock (Tsuga canadensis (L.) Carr.) throughout most of the range of eastern hemlock. Stem injection of insecticide is widely used as a chemical control measure, but the effectiveness of this method depends on the hydraulic characteristics of individual trees. We present data quantifying the distribution of water flux within the stems and the seasonal variability of daily water use of eastern hemlock trees growing in New England, U.S. and the southern Appalachians. We provide simple mathematical and graphical models derived from these data that can be used by landowners, natural resource managers, and tree care specialists to estimate the amount and timing of water use by eastern hemlock based on tree size and climatic conditions. We anticipate that the data and models presented will be useful in improving the effectiveness and efficiency of systemic insecticide applications.
\end{abstract}

Key Words. Adelges tsugae; hemlock; imidacloprid; insecticide; systemic; transpiration; Tsuga spp.; water use.

Eastern hemlock [Tsuga canadensis (L.) Carr.] is one of the longest-lived and most shade-tolerant tree species in eastern North America. The natural range of eastern hemlock extends from the southern Appalachians, U.S. to southern Canada and into the central Lake states (McWilliams and Schmidt 2000). Eastern hemlock has significant functional importance in forests and is highly valued as a landscape species in rural and urban settings. At present, eastern hemlock trees of all ages and sizes in the eastern and southernmost portion of the range are declining and dying as a result of attack by an introduced insect, the hemlock woolly adelgid (HWA; Adelges tsugae Annand) (Orwig et al. 2002; USDA 2006). Because eastern hemlock has no known resistance to HWA, decline is progressive and can occur after 4 or more years of infestation (Orwig et al. 2002).

Chemical control has been quite effective, and application methods include foliar sprays and soil and stem application of systemic insecticides (e.g., imidacloprid, a chloronicotinyl (1-[(6-chloro-3-pyridinyl) methyl]-N-nitro-2-imidazolidinimine) insecticide) (Steward and Horner 1994; Fidgen et al. 2002; Webb et al. 2003; McAvoy et al. 2005; Cowles et al. 2006). Effectiveness of imidacloprid stem applications has varied with injection method, timing, and other tree-specific characteristics (Tattar et al. 1998; Doccola et al. 2005; McAvoy et al. 2005; Cowles et al. 2006). Improving the effectiveness and efficiency of application could not only reduce cost and nontargeted effects (Raupp et al. 2004), but also potentially allow landowners, tree care specialists, and natural resource managers to treat a greater number of trees.
Whether the insecticide is applied directly to the tree through stem injection or indirectly through root uptake from soil water after soil application, the effectiveness and efficiency of the treatment depends on movement of the insecticide through the stem and branch xylem and into the xylem ray parenchyma cells at the base of the needles where the HWA feed. Insecticide delivery is thus dependent on several tree hydraulic characteristics, including the distribution of water flux within the stem, seasonal variation in water use, and tree-to-tree differences in size or habitat that affect the magnitude of and variation in water use. We provide simple mathematical and graphical models derived from data collected from eastern hemlock in both the northern and southern parts of its range that can be used to estimate tree water use based on tree size and climate conditions. These models can be used to ensure that insecticide is applied during periods of rapid water uptake and movement through the tree stem and to maximize its effectiveness.

\section{METHODS}

During 2004 and 2005, we measured stem sap flux of 16 eastern hemlock trees [Tsuga canadensis (L.) Carr.] in the southern Appalachians (SA) and eight eastern hemlock trees in New England (NE) as well as climate variables at both locations. We used constant heat dissipation probes (Granier $1985)$ to measure stem sap flux density. Sap flux density ( $v, \mathrm{~g} \mathrm{H}_{2} \mathrm{O} \mathrm{m} \mathrm{m}^{-2}$ sapwood $\mathrm{s}^{-1}$ ) was determined by installing probes in the outer $2 \mathrm{~cm}(0.8 \mathrm{in})$ of the functional xylem. Probes were installed and shielded from thermal gradients as 
described by Ford and Vose (2007). All lead wires were connected to double-shielded cable wires and differentially connected to a data logger with a multiplexer peripheral (models CR10X and AM416; Campbell Scientific, Inc., Logan, UT). The temperature difference between the upper and lower probes was converted to sap flux density using the equation of Granier (1985). For all trees, readings for the two replicate sets of sensors were averaged. Occasionally, sensors were replaced in newly drilled holes if null, out-of-range, erratic, or negative readings were recorded or if probes were physically damaged. We also used three or more variable length sap flow probes to measure the radial distribution of sap flux within the sapwood in two of the 16 trees in the SA and two of the eight trees in NE. Further descriptions of methods used to measure sap flux and climatic variables can be found in Ford and Vose (2007) and Daley et al. (in press). Trees were considered healthy with minimal (SA) to absent (NE) infestation at the onset of these studies. We use the data we obtained to develop relationships between: 1) water flux and depth into the xylem;2) tree water use and the seasonal variation in water flux; and 3) tree water use and tree size. In addition, we use those data to develop simple mathematical and graphical functions for predicting daily water use by eastern hemlock on the basis of climatic variables and tree diameter.

A multiple variable linear regression approach was used to predict daily water use by eastern hemlock. We treated days as replicate observations; however, one underlying assumption of regression is that replicate observations are independent. Water use observations for an individual tree on successive days are not independent, attributable partially to lag effects associated with capacitance. Seasonally, successive observations often have a high autocorrelation resulting from the influence of factors such as leaf area, sapwood area, climate, and individual genetic effects. To avoid capacitance effects, we subsampled the master data set and only used 7 days of measured water use for each tree. Subsamples had to occur on rain-free days, have measurements from all trees on both sites, and had to represent all seasons (the seven subsampled days were roughly 60 days apart). We assumed that any remaining autocorrelation in the subsampled data set was attributable to seasonal effects and that replicate observations were independent. In other words, we assumed that daily water use measured at one point in time did not directly affect daily water use measured approximately 60 days later and that any trend in the daily water use over time was the result of external factors affecting the tree such as climate and climate effects on seasonal leaf and sapwood area growth.

An additional assumption of regression analysis is that observations are normally distributed. To meet this assumption, daily water use data were natural log-transformed after which data were distributed normally (Shapiro-Wilk test, $P=0.21)$. Because this transformation was used, it was nec- essary to eliminate from consideration 2 days of subsampled observations in the NE data set. These observations were made when transpiration was zero, during January and March. Our final subsampled data set contained 152 observations. Thus, our dependent variable was the natural log of daily water use in each of the 24 trees on 7 days that were sampled $(n=152)$.

The independent variables used in the analysis were regional location, day of year, year, diameter at breast height, daytime average air temperature, and daytime average vapor pressure deficit. We used a forward selection regression approach in which variables were entered into the model each in turn until no remaining variable produced a significant $F$ statistic (SAS 2003). We present two models: one model is more complex, but the independent variables explain more variation in eastern hemlock water use; the second model is less complex and the independent variables explain slightly less variation in water use. We used the less complex model to develop an easy-to-use graphical relationship among tree diameter, average daytime temperature, and total daily water use.

\section{RESULTS AND DISCUSSION Distribution of Water Flux Within the Stem}

The distribution of water flux within the stem was consistent among the four trees monitored. Although diameter of the four trees ranged from 34.6 to $77.7 \mathrm{~cm}$ (13.8 to $31.1 \mathrm{in}$ ), the maximum water flux consistently occurred 1 to $2 \mathrm{~cm}(0.4$ to 0.8 in) beneath the cambium in the xylem (Figure 1). This depth represented $12 \%$ to $30 \%$ of the hydroactive xylem radius in the trees measured. The integrated water flow in the 0 to $2 \mathrm{~cm}$ (0 to $0.8 \mathrm{in}$ ) sapwood region represented 54\% (34.6 $\mathrm{cm}$ [13.8 in] diameter at breast height [dbh]), $74 \%(44.6 \mathrm{~cm}$ [17.8 in] dbh), 23\% (55.3 cm [22.1 in] dbh), and 97\% (77.7 $\mathrm{cm}$ [31.1 in] dbh) of the total flow. Most of the variability in the distribution of water flux was found in the deeper sapwood areas and was largely attributable to the $55.3 \mathrm{~cm}(22.1$ in) dbh tree.

This skewed distribution of water flux in the stem is typical in trees with tracheid xylem elements (Ford et al. 2004) and it can be related to the development and age of the xylem elements. For example, at the cambium interface, newly developed living xylem cells are not yet functional in mass water transport. Xylem cells further away from the cambium are dead and hollow and are thus functional in mass water transport. Over time, these xylem cells become increasingly displaced from the cambium, and they can become progressively more dysfunctional as a result of chemical, biological, and physical disruptions (see discussion and references in Ford et al. 2004). Our data suggest that the greatest movement of stem water generally occurs in zones 1 to $2 \mathrm{~cm}(0.4$ to 0.8 in) past the inner bark. 


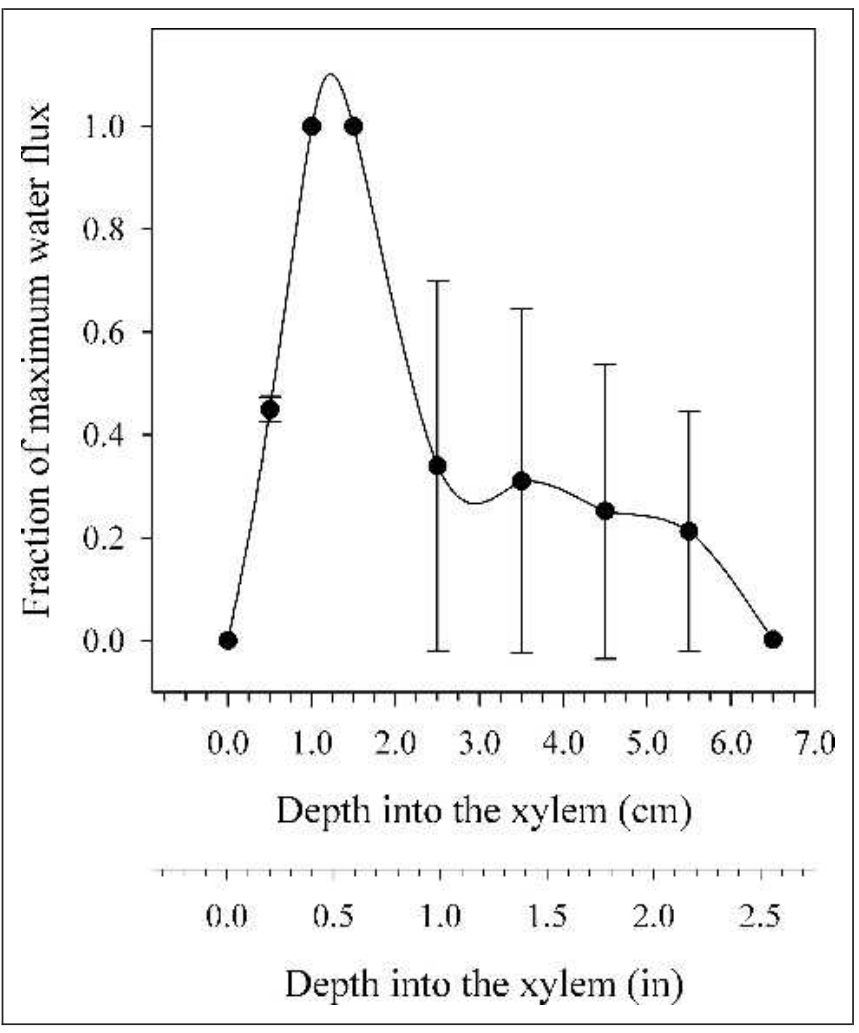

Figure 1. Normalized distribution of water flux in the trunk of two eastern hemlock trees each in the southern Appalachians ( 34.6 and $55.3 \mathrm{~cm}$ ( 13.8 and 22.1 in) diameter at breast height (dbh)) and New England (44.6 and 77.7 $\mathrm{cm}$ (17.8 and $31.1 \mathrm{in}$ ) dbh). Points at 0,0 were assumed, whereas all other points were measured. Points represent the mean normalized flux with standard error bars. No error is shown for 6.5 , because only one tree had sapwood at that depth.

\section{Seasonal Variation in Water Use}

Seasonal variation in daily water use by eastern hemlock differed by region with daily water use peaking in the spring months in the SA and in the summer months in NE (Figure 2). Trees transpired throughout the year in the SA, whereas trees in NE showed no measurable water flux in the winter months. Understanding regional differences in water flux is important for fine-tuning treatment protocols.

Daily water use within region was exponentially related to tree diameter, a relationship that has been found to be consistent across many tree species throughout the world (Meinzer et al. 2005) with smaller diameter trees using significantly less water than larger diameter trees (Figure 3). However, for any given tree size, trees in the SA appeared to have a greater maximum rate of daily water use (Figure 3). Both daily and seasonal variability in water use were related to climatic factors associated with each region and phenological factors associated with tree growth. Region itself did

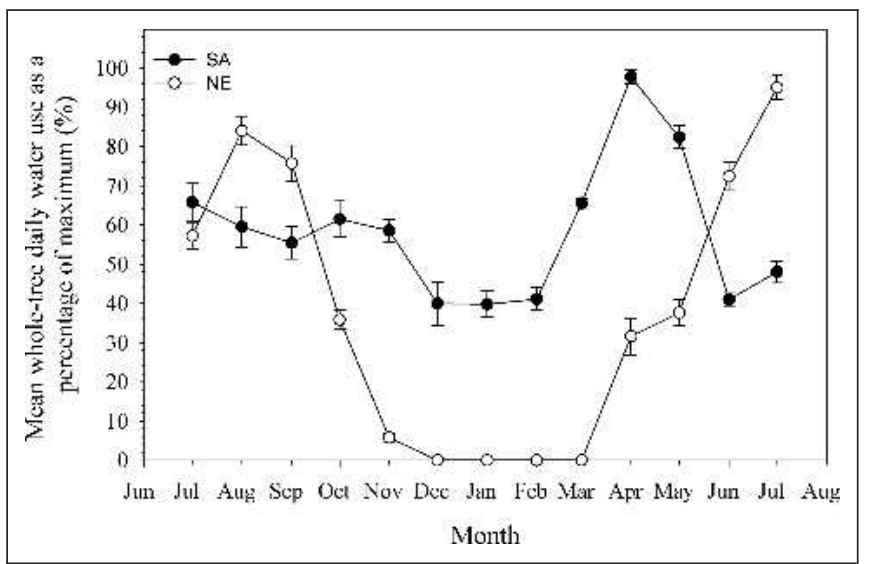

Figure 2. Whole-tree daily water use as a percentage of the maximum whole-tree daily water use measured during the studies for eastern hemlock trees in the southern Appalachians (SA) and New England (NE). Each point corresponds to the average of all measurements at each site.

not explain variability in daily water use beyond what climatic and seasonal variables alone could explain (Table 1). Day of year was positively related to daily water use and most likely served as a surrogate for phenology (i.e., leaf area

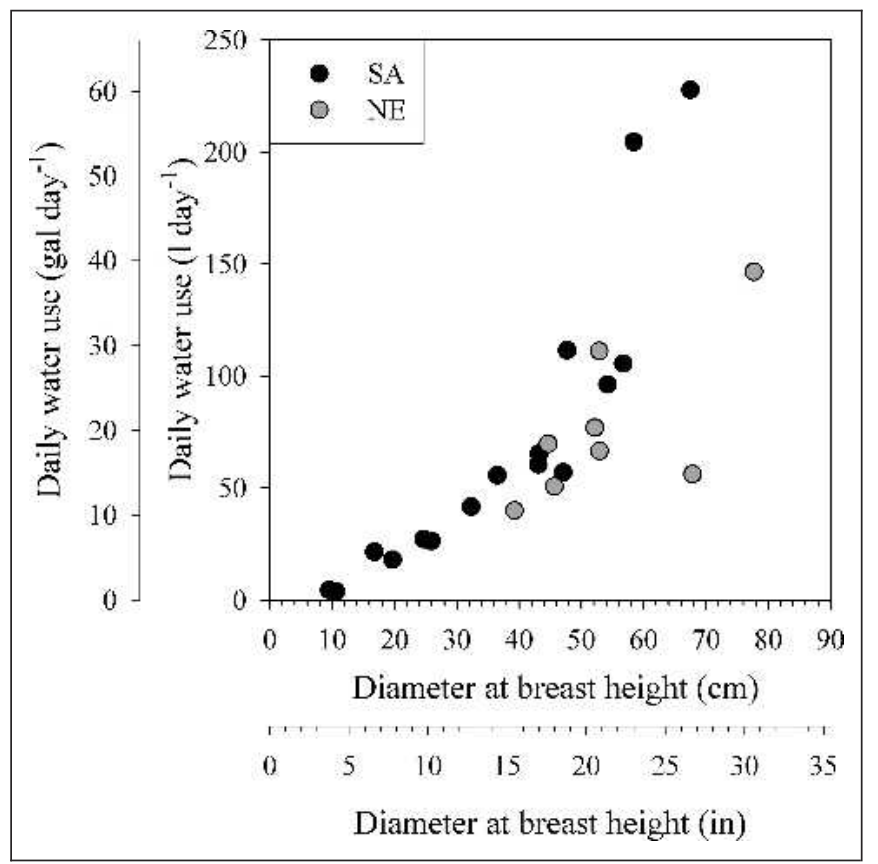

Figure 3. Measured maximum daily water use for eastern hemlock trees in the southern Appalachians (Coweeta, NC, 26 May 2004; SA) and New England (Harvard Forest, MA, 24 August 2004; NE) during peak seasonal transpiration. 
Table 1. Predictive multiple-variable linear regression equations for eastern hemlock whole-tree daily water use (dwu, L water per day $\left.^{-1}\right)^{2}$

\begin{tabular}{llll}
\hline Model & Equation & Adjusted $R^{2}$ & $F$ statistic \\
\hline 1 & $\ln (d w u)=-1.33+0.061(d b h)+0.027($ avg_T $)+0.003($ doy $)+0.676(v p d)$ & 0.83 & 181.74 \\
2 & $\ln (d w u)=-0.970+0.061(d b h)+0.071($ avg_T $)$ & 0.78 & 269.04 \\
\hline
\end{tabular}

${ }^{\mathrm{z}}$ Independent variable descriptions and corresponding units are: 1) diameter at breast height (dbh, $\left.\mathrm{cm}\right) ; 2$ ) average daytime air temperature (avg_T, $\left.\left.{ }^{\circ} \mathrm{C}\right) ; 3\right)$ day of year (doy, julian); and 4) average daytime vapor pressure deficit (vpd, $\mathrm{kPa}$ ). For all predictors, $P>|\mathrm{t}|$ was less than 0.01 . Both models were significant at $P<0.001$

expansion through time and sapwood growth through time) and evaporative demand.

The more complex model predicting daily water use by eastern hemlock included tree diameter, average daytime air temperature, day of year, and daytime average vapor pressure deficit as variables (Table 1). The order of the variables in this model corresponds to their predictive ability. The simpler model included tree diameter and average daytime air temperature as predictor variables (Table 1; Figure 4). Although the more complex model had greater predictive ability than the less complex model (Table 1), both models performed well (adjusted $R^{2}$ was 0.83 for the more complex model and 0.78 for the simpler model).

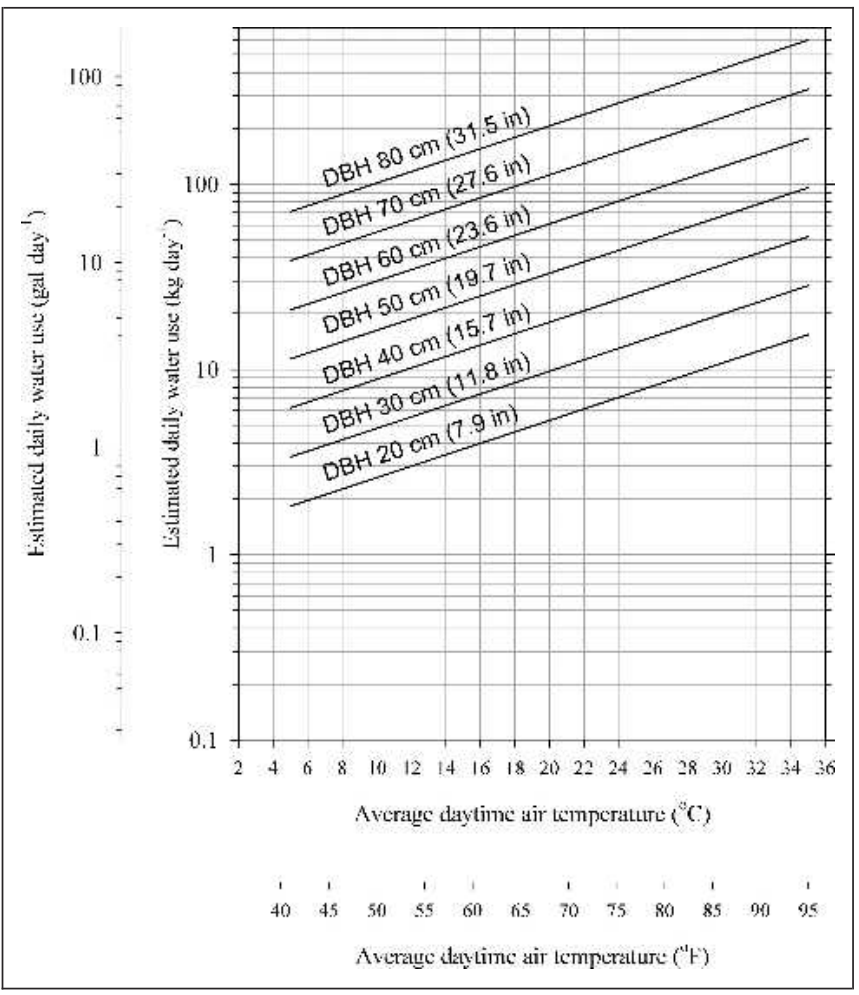

Figure 4. Estimated whole-tree daily water use of eastern hemlock trees of varying diameter at breast height (dbh, $\mathrm{cm}$ ) as a function of mean daytime air temperature predicted by model 2 in Table 1.

\section{Potential Application of Models}

The strongest predictor of whole-tree daily water use in eastern hemlock was tree size (i.e., dbh). The exponential relationship between mass flow of water and tree size (Figure 3) in eastern hemlock means that an exponential volume or mass of insecticide should also be applied to trees per unit diameter to achieve a consistent and known concentration in the tree xylem sap across tree sizes. Yet, most studies report using a constant dosage per unit diameter, consistent with the manufacturer-recommended dosage (Fidgen et al. 2002; Webb et al. 2003; Doccola et al. 2005; McAvoy et al. 2005). The dosages used in all four studies previously mentioned would result in a higher concentration of imidacloprid for smaller diameter trees than for larger ones. For example, if the recommended dosage is $0.55 \mathrm{~g} / \mathrm{cm}^{-1}\left(1.4 \mathrm{~g} / \mathrm{in}^{-1}\right) \mathrm{dbh}$, an $80 \mathrm{~cm}$ (32 in) tree would receive $44 \mathrm{~g}(1.54 \mathrm{oz})$ of active ingredient (AI), whereas a $20 \mathrm{~cm}(8 \mathrm{in})$ tree would receive $11 \mathrm{~g}(0.39 \mathrm{oz})$ of AI. Based on our measurements and models of water use, an $80 \mathrm{~cm}(32 \mathrm{in})$ tree growing at $20^{\circ} \mathrm{C}\left(68^{\circ} \mathrm{F}\right)$ mean daytime temperature would use $200 \mathrm{~L}$ (52 gal) of water per day, resulting in a mean concentration of $0.22 \mathrm{~g}(0.01 \mathrm{oz}) \mathrm{AI} \mathrm{L}^{-1}$ per day ${ }^{-1}\left(0.83 \mathrm{~g}^{0} 0.03 \mathrm{oz}\right] \mathrm{AI} \mathrm{gal}^{-1}$ per day $\left.{ }^{-1}\right)$ (assuming that all of the chemical was released from the capsule in one day, concentrations would even lower if the chemical were released over several days). By contrast, a $20 \mathrm{~cm}$ (8 in) tree would use $5 \mathrm{~L}$ ( $1.3 \mathrm{gal})$ of water per day, resulting in a mean concentration of $2.2 \mathrm{~g}(0.08 \mathrm{oz}) \mathrm{AI} \mathrm{L}^{-1}$ per day $^{-1}(8.3 \mathrm{~g} \mathrm{[0.29}$ oz] AI gal ${ }^{-1}$ per day ${ }^{-1}$ ). This 10-fold difference in imidacloprid concentration could affect the effectiveness of HWA treatments.

The physio- and biochemical processes involved with root (from soil application) or stem uptake (from stem injection), dissolution in the xylem stream, movement to the leaves and twigs, and symplastic and apoplastic translocation of imidacloprid are complex and beyond the scope of this study. However, as recent studies show, the concentration of imidacloprid in the sap is highly correlated with HWA mortality. For example, varying the concentration of imidacloprid in water taken up by excised stems has been shown to directly affect HWA mortality (Cowles et al. 2006). Specifically, with each order of magnitude increase in concentration of $\mathrm{AI}$ in water taken up through the stems of excised infested branches, HWA mortality increased roughly $30 \%$. A concentration of 
roughly $100 \mathrm{ppm}$ in the water taken up by the stem should result in 100\% mortality of HWA (Cowles et al. 2006). Effective xylem sap concentration reported by Cowles et al. (2006) could be combined with our estimates of daily water use by hemlock to calculate dosages that would result in consistent concentrations for hemlocks of various sizes growing under various climatic conditions (Figure 4). Although our results suggest that current dosage recommendations yield sap concentrations that may be too low in large trees for maximum effectiveness, our results are speculative because we have not validated this (e.g., we have not measured concentrations in the tissues or measured HWA mortality). Cause and effect understanding will require detailed studies of the mechanisms underlying imidacloprid translocation. Until these cause and effect relationships are known, concentrations of AI in hemlock xylem sap may be a good indicator of the efficacy of injections, and dosage recommendations by the pesticide manufacturers could be refined with the additional information provided by our water use models.

The models presented here may also help practitioners determine injection depth and application timing throughout the range of eastern hemlock. Our data show that more than 50\% of the water movement in the stem occurs in the outer $2 \mathrm{~cm}$ (0.8 in) of the xylem. Ensuring that injections do not penetrate deeper than $2 \mathrm{~cm}$ (0.8 in) will limit stem wounding and maximize potential delivery. In addition, because water use varies seasonally, the timing of stem injections may determine the efficacy of treatment. For example, in the SA, if stem injections are timed to occur during peak water uptake and transport (e.g., April), then potential delivery of the insecticide to the xylem ray parenchyma at the base of the needles will likely coincide with peak feeding activity of HWA (Ward et al. 2004).

The water flux data and models may be useful in improving the effectiveness and efficiency of systemic insecticide applications in eastern hemlock. More complex and robust models have been developed to predict eastern hemlock water use in the southern Appalachians (Ford and Vose 2007). However, our goal in developing the models presented was to create tools that could be used by tree care professionals to easily estimate eastern hemlock water use. Because these models were developed using transpiration data for healthy eastern hemlocks measured on rain-free days, the model predictions are most relevant under similar conditions. Lastly, our data show: 1) that maximum water movement occurs 1 to $2 \mathrm{~cm}$ (0.4 to 0.8 in) past the inner bark; 2) that seasonal patterns of water use by eastern hemlock vary considerably from region to region, with maximum water use occurring in the spring (March to May) in the southern portion of the range and in the summer (June to August) in the northeastern portion of the range; and 3) water use is exponentially related to tree size.

\section{Copyright Statement}

This article was written and prepared by U.S. Government employees on official time, and it is therefore in the public domain and not subject to copyright.

\section{Pesticide Precautionary Statement}

Pesticides used improperly can be injurious to humans, animals, and plants. Follow the directions and heed all precautions on the labels. Store pesticides in original containers under lock and key, out of the reach of children and animals, and away from food and feed. Apply pesticides so that they do not endanger humans, livestock, crops, beneficial insects, fish, and wildlife. Do not apply pesticides when there is danger of drift, when honey bees or other pollinating insects are visiting plants, or in ways that may contaminate water or leave illegal residues. Avoid prolonged inhalation of pesticide sprays or dusts; wear protective clothing and equipment if specified on the container. If your hands become contaminated with a pesticide, do not eat or drink until you have washed. In case a pesticide is swallowed or gets in the eyes, follow the first aid treatment given on the label and get prompt medical attention. If a pesticide is spilled on your skin or clothing, remove clothing immediately and wash skin thoroughly. Do not clean spray equipment or dump excess spray material near ponds, streams, or wells. Because it is difficult to remove all traces of herbicides from equipment, do not use the same equipment for insecticides or fungicides that you use for herbicides. Dispose of empty pesticide containers promptly. Have them buried at a sanitary landfill dump or crush and bury them in a level, isolated place.

NOTE: Some states have restrictions on the use of certain pesticides. Check your state and local regulations. Also, because registrations of pesticides are under constant review by the Federal Environmental Protection Agency, consult your county agricultural agent or state extension specialist to be sure the intended use is still registered.

Acknowledgments. We thank M.E. Montgomery and R.M. Hubbard for helpful comments on an earlier version of this article.

\section{LITERATURE CITED}

Cowles, R.S., M.E. Montgomery, and C.A.S.-J. Cheah. 2006. Activity and residues of imidacloprid applied to soil and tree trunks to control hemlock woolly adelgid (Hemiptera: Adelgidae) in forests. Journal of Economic Entomology 99:1258-1267.

Daley, M.J., N.G. Phillips, J.C. Pettijohn, and J.L. Hadley. Water use by eastern hemlock (Tsuga Canadensis) and black birch (Betula lenta): Implications of effects of the hemlock woolly agelgid. Canadian Journal of Forest Research (in press).

Doccola, J.J., I. Ramasamy, P. Castillo, C. Taylor, and S. Sifleet. 2005. Erratum: Efficacy of Arborjet VIPER microinjections in the management of hemlock woolly ad- 
elgid (Adelges tsugae). Journal of Arboriculture 31: 203-206.

Fidgen, J.G., Q.C. McClellan, and S.M. Salom. 2002. Efficacy and residual activity of two systemic insecticides for control of hemlock woolly adelgid on young eastern hemlocks. Hemlock Woolly Adelgid in the Eastern United States Symposium, East Brunswick, NJ, USDA Forest Service.

Ford, C.R., M.A. McGuire, R.J. Mitchell, and R.O. Teskey. 2004. Assessing variation in the radial profile of sap flux density in Pinus species and its effect on daily water use. Tree Physiology 24:241-249.

Ford, C.R., and J.M. Vose. 2007. Tsuga canadensis (L.) Carr. mortality will impact hydrologic processes in southern Appalachian forest ecosystems. Ecological Applications 17:1156-1167.

Granier, A. 1985. Une nouvelle méthode pour la mesure du flux de sève brute dans le tronc des arbres. Annales Des Sciences Forestieres 42:193-200.

McAvoy, T., W.T. Mays, S.M. Salom, and L.T. Kok. 2005. Impact of imidacloprid on hemlock woolly adelgid and water quality at Mt. Lake, Virginia. 3rd Symposium on Hemlock Woolly Adelgid in the Eastern United States, Asheville, NC, USDA Forest Service.

McWilliams, W.H., and T.L. Schmidt. 2000. Composition, structure, and sustainability of hemlock ecosystems in eastern North America. Symposium on Sustainable Management of Hemlock Ecosystems in Eastern North America, Durham, NH, USDA Forest Service.

Meinzer, F.C., B.J. Bond, J.M. Warren, and D.R. Woodruff. 2005. Does water transport scale universally with tree size? Functional Ecology 19:558-565.

Orwig, D.A., D.R. Foster, and D.L. Mausel. 2002. Landscape patterns of hemlock decline in New England due to the introduced hemlock woolly adelgid. Journal of Biogeography 29:1475-1487.

Raupp, M.J., R.E. Webb, A. Szczepaniec, D. Booth, and R. Ahern. 2004. Incidence, abundance, and severity of mites on hemlocks following applications of imidacloprid. Journal of Arboriculture 30:108-113.

SAS. 2003. SAS/STAT Software: User's Guide, Version 9.1. SAS Institute, Inc., Cary, NC.

Steward, V.B., and T.A. Horner. 1994. Control of hemlock woolly adelgid using soil injections of systemic insecticides. Journal of Arboriculture 20:287-288.

Tattar, T.A., J.A. Dotson, M.S. Ruizzo, and V.B. Steward. 1998. Translocation of imidacloprid in three tree species when trunk- and soil-injected. Journal of Arboriculture 24:54-56.

USDA. 2006. Hemlock Woolly Adelgid Infestation Map2005, USDA Forest Service GIS Group, Durham, NH.

Ward, J.S., C.A.S.-J. Cheah, M.E. Montgomery, B.P. Onken, and R.S. Cowles. 2004. Eastern Hemlock Forests: Guide- lines to Minimize the Impacts of Hemlock Woolly Adelgid. USDA Forest Service, Morgantown, WV.

Webb, R.E., J.R. Frank, and M.J. Raupp. 2003. Eastern hemlock recovery from hemlock woolly adelgid damage following imidacloprid therapy. Journal of Arboriculture 29: 298-302.

Chelcy R. Ford (corresponding author)

Research Ecologist

USDA FS SRS Coweeta Hydrologic Lab

3160 Coweeta Lab Rd.

Otto, NC 28763, U.S.

crford@fs.fed.us

James M. Vose

Project Leader and Research Ecologist

USDA FS SRS Coweeta Hydrologic Lab

3160 Coweeta Lab Rd.

Otto, NC 28763, U.S.

Michael Daley

Geography Department

Boston University

675 Commonwealth Ave.

Boston, MA 02215, U.S.

Nathan Phillips

Associate Professor

Geography Department

Boston University

675 Commonwealth Ave.

Boston, MA 02215, U.S.

Résumé. Le puceron lanigère de la pruche (HWA, Adelges tsugae Annand) cause un déclin et une mortalité généralisée de la pruche du Canada (Tsuga canadensis (L.) Carr.) au sein de l'ensemble de l'aire de distribution de cette pruche. L'injection dans le tronc d'insecticide est largement employée comme mesure de contrôle chimique, mais l'efficacité de cette méthode dépend des caractéristiques hydrauliques de l'arbre individuel. Dans cet article, on y présente des données quantifiant la distribution du flux en eau à l'intérieur des tiges ainsi que la variabilité saisonnière de l'utilisation journalière en eau chez la pruche du Canada poussant en Nouvelle-Angleterre et dans le Sud des Appalaches. On y fournit des modèles mathématiques et graphiques simples dérivés à partir de ces données qui peuvent être utilisés par les propriétaires, les gestionnaires de ressources naturelles et les spécialistes en entretien des arbres afin d'estimer la quantité et le moment d'utilisation de l'eau par la pruche du Canada, et ce en se basant sur la dimension de l'arbre et les conditions climatiques. On anticipe que les données et les modèles présentés vont constituer une amélioration importante de l'efficience et de l'efficacité des applications d'insecticide chimique. 
Zusammenfassung. Die Douglasien-Wollschildlaus verursacht einen weit verbreiteten Schaden und Absterben bei Tsuga canadensis. Die Stamminjektion von Insektiziden wird oft als chemische Bekämpfung eingesetzt, aber die Effektivität dieser Methode ist abhängig von den hydraulischen Charakteristika des individuellen Baumes. In dieser Studie präsentieren wir Daten zur Quantifizierung der Verteilung von Zellwasser in den Stämmen und der saisonalen Abweichung von täglichem, Wasserbedarf der Douglasien in NeuEngland und den südlichen Appalachen. Wir liefern simple mathematische und graphische Modelle, die sich aus den erhobenen Daten entwickelten, die von Landeigentümern, ResourcenManagern und Baumpflegern benutzt werden können, um die Menge und den Zeitpunkt des Wasserverbrauchs von Douglasien, basierend auf der Baumgröße und den klimatischen Bedingungen zu schätzen. Wir gehen davon aus, dass die präsentierten Daten und Modelle nützlich bei der Verbesserung der Effektivität und Effizienz von applizierten systemischen Insektiziden sein können.
Resumen. El aldégido (HWA, Adelges tsugae Annand) es el causante de la dispersión de la declinación y mortalidad del abeto del este (Tsuga canadensis (L.) Carr.), en su rango de distribución. La inyección al tronco de insecticida es ampliamente utilizada como una medida de control químico, pero la efectividad de este método depende de las características hidráulicas de los árboles individuales. En este reporte presentamos datos cuantificando la distribución del flujo de agua dentro de los tallos y la variabilidad estacional del uso diario del agua de los abetos en New England y el sureste de los Apalaches. Se proporcionan modelos matemáticos y gráficos simples derivados de estos datos que pueden ser usados por los propietarios, lo manejadores de recursos naturales y los especialistas en el cuidado de los árboles para estimar la cantidad y períodos de uso del agua con base en el tamaño del árbol y las condiciones climáticas. Se anticipa que los datos y los modelos presentados serán útiles para mejorar la eficiencia y efectividad de las aplicaciones de insecticidas sistémicos. 